INTERNATIONAL JOURNAL OF RESEARCHES IN BIOSCIENCES, AGRICULTURE AND TECHNOLOGY (C) VISHWASHANTI MULTIPURPOSE SOCIETY (Global Peace Multipurpose Society) R. No. MH-659/13(N) www.ijrbat.in

\title{
EFFECTS OF VERMIWASH ON SEED GERMINATION AND SEEDLING GROWTH IN CATHARANTHUS ROSEUS - A POTENT BIOFERTILIZER
}

Sheikh Shagufta Amir1, Dakhane P. Vimal2

1. Ph.D. Scholar, Department of Botany, Dr. Ambedkar College of Arts, Commerce and Science, Chandrapur, Gondwana University, Gadchiroli - 442605, Maharashra, India.

2. Assistant Professor, Department of Botany, Dr. Ambedkar College of Arts, Commerce and Science, Chandrapur, Gondwana University, Gadchiroli - 442605, Maharashtra, India.

*1Corrosponding author :shagufta_21jan@rediffmail.com, shaguftasheikh211@gmail.com

\begin{abstract}
:
Catharanthus roseus (Linn.) G. Don is an important medicinal plant belongs to the Apocynaceae family grows wild in the Indian subcontinent in Southern Asia. Improvement of seed germination may enable commercial propagation of this plant. The experiment was carried out to study the effect of vermiwash on seed germination and seedling vigour of Catharanthus roseus during the two seasons of 2014-2015 and 2015-2016. Data based on various parameters like germination (\%), root / shoot (R/S) ratio, Vigour Index (VI) was observed. The highest seed germination percentage, seedling characteristics (shoot length, root length), VI were obtained from treatment of soil with $80 \%$ vermiwash could be effective and hence used directly in soil for seed germination and seedling growth improvements in Catharanthusroseus.
\end{abstract}

Keywords: Catharanthus roseus, vermiwash, germination (\%), Vigour Index, seedling growth.

\section{INTRODUCTION:}

Herbal medicine also known as phytomedicine because of using plant seeds, flowers, roots for medicinal purpose and play an important role in drug discovery. Popularity of herbal drugs is increasing all over day by day in the world because of their lesser side effects as compared to synthetic drugs (Rout and Ghadai, 2012). Medicinal and aromatic plants are known to be used by $80 \%$ of global population for their medicinal therapeutic effects (WHO, 2008).

Catharanthus roseus is an important medicinal evergreen herb of the family apocynaceae and generally known as Vincarosea. The plant is also found abundantly grown in the home gardens. Despite having common look it has very powerful medicinal properties which are due to the alkaloids present in it. Out of the several alkaloids found in it Vincristine and Vinblastine are commonly used in cancer therapy whereas ajmalicine and serpentine are used as antihypertensive and sedative compound (Gaines, 2004). Catharanthus roseus is an Indian originated herb which grows wild in the subcontinent in Southern Asia (Asheesh Kumar et al., 2012). This species was selected for the present study because it has high medicinal value. Seed germination and early seedling growth are considered the most critical phases for establishment of any species and hence, it is commonly emphasized that tolerance of seeds to various stresses during germination should be maintained. The propagation of Catharanthus roseus generally occurs through seeds and can be grow in sandy, loamy soil rich in organic matter is good for its growth and yield.

There are several organic fertilizers in the form of Vermicompost and Farm yard manure that have been applied producing phenomenal increase in yield and quality. Recently the use of Liquid fertilizers given in the form of foliar sprays has gained tremendous importance. The advantages of using the liquid fertilizer, has increased the need for the production of several such materials \& to be used as foliar sprays. Vermiwash in a liquid fertilizer used in organic agriculture both as replacement and supplement for solids and for their unique capacity to provide effective and quick nutrients. Vermiwash (VW), generally used as a 
foliar spray, is a liquid biofertilizer collected by the passage of water through a column of worm activation. In recent years many studies have reported that vermiwash as foliar spray which was effective for growth. There are reports by Lalitha et.al. (2000), Zambare et al. (2007), Ansari and Ismail (2001) and Shiva Subramanian and Ganeshwar (2004) for the effectiveness of vermiwash as a biofertiliser helping in organic farming. Very Scanty work is done on this aspect in Catharanthus roseus. In view, of the above, the present investigation conducted with an objective to assess the improvement of seed germination in Catharanthus roseus.

\section{METHOD AND MATERIAL:}

\section{Collection of experimental material:}

Seed germination was studied in pot under favourable atmospheric condition. Seeds of Catharanthus roseus were collected from local garden of Gadchiroli, India for germination studies and stored for a month in air tight plastic bags with $\mathrm{BHC}$ powder to protect them from insects and other infections at room temperature until used for experiment.

\section{Preparation of Vermiwash:}

About 1 litre of vermiwash was produced by the action of Earthworm (Perionyx excavates) was collected from Wakdi nursery, Gadchiroli, (M.S.), India for the experiment. Aqueous solution of various concentrations of Vermiwash (20\%, 40\%, $60 \%, 80 \%, 100 \%$ ) was prepared. Control (water) was also maintained in parallel with treated material.

\section{Germination studies:}

To study the effect of vermiwash on germination of the seeds, thirty seeds were sown in each small pot containing field soil and treatments were given as per (Table-1) viz. feld soil $+20 \%$ vermiwash, field soil $+40 \%$ vermiwash, field soil $+60 \%$ vermiwash, field soil $+80 \%$ vermiwash, field soil $+100 \%$ vermiwash (vw), field soil + water as Control.

The soil analysis of different soil compositions used under present study was carried out at Agricultural Science Centre, Soil Testing Laboratory, Sonapur,
District - Gadchiroli, Maharashtra, India (Table-2). Three pots were maintained for each treatment. The effect of the vermiwash treatment on seed germination of Catharanthus roseus was studied by treating the seeds with water in field soil for one set which served as the control, for other sets, seeds were treated with various vermiwash concentrations depending upon the moisture condition of soil. Seeds were observed daily for the emergence of radical. The observations were done for 30 day. After 30 day of setting the experiment, seed germination percentage, root and shoot length of seedlings were recorded.

\section{Statistical Analyses:}

The results obtained were statistically analyzed according to the equation of ISTA.

Germination Percentage $=($ No. of germinated seeds)/(Total No.of seeds sown) x100

The seedling vigour index (VI) was calculated according to Abdul-Baki and Anderson (1973) following formula:

$\mathrm{VI}=$ percentage of germination $\mathrm{X}$ seedling length (cm)

Where, seedling lengths are the sum of root and shoot length.

The mean values of data obtained from six replicates during the both years and statistically analyzed by One Way ANOVA as suggested by Gomez and Gomez (1984).

\section{RESULT AND DISCUSSION:}

The various aspects of study viz-germination percentage, Root/Shoot ratio, root length, shoot length, Vigour Index (VI), Germination Value (GV) were done in soil with vermiwash grown seeds of Catharanthus roseus. Studies on germination were done to determine how vermiwash affects the germination rate and brings about enhancement of seedling growth. Seed germination results of Catharanthus roseus in soil conditions with vermiwash (Table-1) shows that the 1st and 2nd season seeds exhibited $100 \%$ seed germination in soil $+80 \%$ vermiwash (T4) and soil $+100 \%$ vermiwash (T5). 93.34\%, 96.66\%, and 86.67\%, $96.66 \%$ were also noticed in seeds sown with soil + $20 \%$ vermiwash (T1) and soil $+40 \%$ vermiwash (T2). 
The soil $+60 \%$ vermiwsh (T3), treated seeds had a $76.67 \%$ and $80.00 \%$ of germination. The minimum germination percentages $56.67 \%$ and $60.00 \%$ were recorded in control (T0) respectively. Fathima and Malathy (2014) observed that vemiwash along with GA3 resulted higher seed germination and seedling growth in Hibiscus sabdariffa and Phaseolus vulgaris. In addition to this, Lalitha et.al. (2000) also given earlier reports on productivity and growth in Abelmoschus esculentus. Joshi and Vig (2010) reported the positive effects of $15 \%$ vermiwash on germination percentage was found to be best and significantly enhanced the yield and quality of Lycopersicum esculentum (L.).

Seedling Growth Characters:

The seedling characters observed were root length and shoot length. The results showed that, root length was observed to be maximum $7.98 \mathrm{~cm}$ and $7.85 \mathrm{~cm}$ in seeds sown with soil $+80 \%$ vermiwash (T4) while, the minimum root length $4.41 \mathrm{~cm}$ and $4.38 \mathrm{~cm}$ were recorded in soil $+20 \%$ vermiwash (T1) as compared to $5.07 \mathrm{~cm}$ and $5.13 \mathrm{~cm}$. in control (T0) respectively in the 2 nd and $1 \mathrm{st}$ season. These results clearly indicate that vermiwash can be exploited as a potent biofertilizer and foliar spray. However Kaur et al. (2015) recorded the maximum root length and plant biomass in Abelmoschus esculentus after using 15\% vermiwash similarly Varghese and Prabha (2014) who reported that vermiwash treated Capsicum frutescens showed increased root, shoot length and number of leaves after 30 days than the vermiwash untreated plants. It was also found that Mujeera Fathima and Malathy Sekar (2014) conducted a study to evaluated the growth promoting effect of 10 $\%$ and $20 \%$ vermiwash was effective in bringing about seed germination and seedling growth in Hibiscus sabdariffa and Phaseolus vulgaris. The results obtained in the present study are in accordance with the earlier observations of Adil Ansari and Kumar Sukhraj (2010), Lalitha et al. (2000) and Ansari (2008 a and b).
The results showed maximum shoot length $14.29 \mathrm{~cm}$, $4.24 \mathrm{~cm})$ while, minimum shoot length (3.52 and $3.49 \mathrm{~cm}$ ) were observed in seeds sown with soil + $80 \%$ vermiwash (T4) and soil + water in control (T0), respectively in 2 nd and 1 st season. It was also observed that Sundararasu et al. (2014) conducted a study to evaluate the effect of vermiwash on growth and productivity of brinjal plants.

The maximum R/S ratio $2.043 \mathrm{~cm}$ and $2.053 \mathrm{~cm}$ was observed in soil $+80 \%$ vermiwash (T4) as compared to other treatments while minimum R/S ratio $1.202 \mathrm{~cm}$ and $1.194 \mathrm{~cm}$ was recorded in soil + 20\% vermiwash (T1), as compared to control (T0) during 1 st and 2 nd season.

The maximum VI $(1261.9 \mathrm{~cm})$ and minimum VI $(431.4 \mathrm{~cm})$ was recorded in seeds with soil $+60 \%$ vermiwash (T3) and soil + water in control (TO) while, $1227 \mathrm{~cm}$ was recorded in seeds with soil + $80 \%$ vermiwash (T4) and $519 \mathrm{~cm}$ in seeds with soil + water as control (T0) respectively, in the 1st and 2nd season. Furthermore, from above observations the maximum GV $(22.42 \mathrm{~cm}, 22.41 \mathrm{~cm})$ and minimum GV $(6.25 \mathrm{~cm}, 6.25 \mathrm{~cm})$ were observed in soil $+20 \%$, $40 \%$ vermiwash and soil $+80 \%, 100 \%$ vermiwash respectively, in the 1 st and 2 nd season.

The results of soil testing in Table-2 indicate the variation in soil parameter viz. EC (dsm-1), Organic carbon, Nitrogen, Phosphate and Potassium with various concentrations of vermiwash. The germination percentage, $\mathrm{R} / \mathrm{S}$ ratio and VI varied in different soil types. The data were significant at $95 \%$ probability level.

\section{CONCLUSION:}

Amongst all concentrations 80\% vermiwash gave better response for seed germination, root length, shoot length, R/S ratio during 1 st and 2 nd season. Vigour index (VI) increases in 2nd season. 40\% vermiwash gave better response to germination value $(\mathrm{GV})$ during both the seasons. Hence the findings of the present study concluded that, vermiwash can be used as a powerful biofertilizer to 
improve the germination and seedling growth rates in Catharanthus roseus.

\section{REFERANCE :}

Abdul-Baki A. A. and Anderson J. D. (1973): "Vigour determination in soyabean seed by multiple criteria", Crop Science.

Ansari A. A. (2008b): Effect of vermicompost and vermiwash on the productivity of Spinach (Spinacia oleracea), onion (Alliumcepa) And Turnip (Brassica compestris). World Jour. Aqric. Sci. 4(3):Pp. 333-336.

Ansari A. A. (2008a): Effect of vermicompost and vermiwash on the productivity of Spinach (Spinacia oleracea), onion (Alliumcepa) and Potato. (Solanumtuberosum). World Jour. Agric. Sci. 4(5): Pp. 554-557.

Ansari, A. A. and Sukhraj K. (2010): Effect of Vermiwash and Vermicompost on soil parameters and productivity of Okra (Abelmoschus esculentus) in Guyana. African Jour. of Agricultural research Vol. 5(14) : Pp.1794-1798.

Ansari, A. A., (2008): "Effect of vermicompost and vermiwash on the productivity of spinach Spinacia oleracea, onion Allium cepa and potato Solanumtuberosum". World jour. of Agricultural Sciences.

Asheeshkumar., Singhal, K.C., Sharma, R. A., Govind K. V., Vinod Kumar. (2012): Analysis of Antioxidant activity of Catharanthus roseusL. and its Association with Habitat Temperature. Asian jour. Exp. Biol. Sci. 3(4) :Pp. 706-713.

Fathima M. and Malathy S. (2014): "Studies on growth Promoting effects of Vermiwash on the germination of Vegetable Crops”. Intern.Jour. of Current Microbiol and Applied Sciences.

Gaines J. L. (2004): Increasing alkaloid production from Catharanthus roseus suspensions through methyl jasmonate elicitation. Pharm. Eng. Jour. 24 :Pp. 24-35.

Gomez K. A. and Gomez A. A. (1984): "Statistical Procedures for Agricultural Research, (2nd ed.) John wiley\&sons., New York. USA.

ISTA. (1999): "International Rules for Seed Testing”. Seed Science and Technology.
Joshi, R. and Vig, R. (2010): "Effect of vermicompost on Growth, Yield and Quality of Tomato (Lycopersicum esculentum L.)." African jour. of Basic and Applied Sciences.

Kaur, P., Bhardwaj, M. and Babbar, I. (2015): "Effect of vermicompost and vermiwash on growth of Vegetables". Research Jour. of Animal, Veterinary and Fishery Sciences, Amritsar, Punjab, India.

Lalitha, R., Fathima, K. and Ismail S. A. (2000): The impact of biopesticide and microbial fertilizers on productivity and growth of Abelmoschusesculentus. Vasundara the earth (1-2) :Pp. 4-9.

Rout, S., Rout, S. and Ghadai, A. (2012): Phytoceutical evaluation and antimicrobial properties of Ecliptaalba and Tylophoraindica. Inter. Jour. of Microbiology Research, 4(5): Pp. 227-230.

Shivasubramanian, K. and Ganeshkumar M. (2004): Influence of vermiwash on Biological productivity of Marigold. Madras Agricultural Jourl. 91: Pp. 221-225.

Sundararasu, K. and Jeyasankar A. (2014): "Effect of vermiwash on growth and yield of brinjal, Solanummelongena (eggplant or aubergine)". Asian Jour. of Science and Technology.

Varghese, S. M. and Prabha, M. L. (2014): "Biochemical characterization of vermiwash and its Effects on growth of Capsicum frutescens". Malaya Jour. Biosciences.

World Health Organization (WHO) (2008): Media Centre, Traditional medicine.

Zambare, V. P., Padul, M. V., Yadav, A. A. and Shete T. B. (2008): Vermiwash : Biochemical and microbiologi- cal approach as ecofriendly soil conditioner. ARPN. Jour. of Agricultural and Biological science 3(4):Pp. 28-37. 

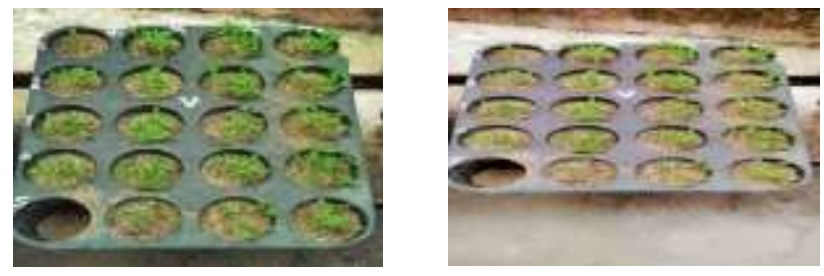

Figure-(1\&2) showing seed germination improvement in diff

Table-1: Effects of different concentrations of ve1miwasn un seeu germmanun anu secuml growth in Catharanthusroseus

\begin{tabular}{|c|c|c|c|c|c|c|c|c|c|c|c|c|}
\hline \multirow{2}{*}{$\begin{array}{l}\text { Sr. } \\
\text { No. }\end{array}$} & \multirow[b]{2}{*}{ Treatments } & \multirow{2}{*}{$\begin{array}{c}\text { Vermiwash } \\
\text { Concentration } \\
(\%)\end{array}$} & \multicolumn{2}{|c|}{ Germination (\%) } & \multicolumn{2}{|c|}{ Root Length (cm) } & \multicolumn{2}{|c|}{ Shoot Length $(\mathrm{cm})$} & \multicolumn{2}{|c|}{ R/S Ratio } & \multicolumn{2}{|c|}{ VI } \\
\hline & & & $1^{\text {st }}$ & $2^{\text {nd }}$ & $1^{\text {st }}$ & $2^{\text {nd }}$ & $1^{\text {st }}$ & $2^{\text {nd }}$ & $1^{\text {st }}$ & $2^{\text {nd }}$ & $1^{\text {st }}$ & $2^{\text {nd }}$ \\
\hline 1. & TO & Control & 56.67 & 60.00 & 5.07 & 5.13 & 3.49 & 3.52 & 1.454 & 1.459 & 431.469 & 519 \\
\hline 2. & $\mathrm{~T} 1$ & $\mathrm{~S}+20 \% \mathrm{vw}$ & 93.34 & 96.66 & 4.38 & 4.41 & 3.68 & 3.72 & 1.202 & 1.194 & 752.320 & 785.84 \\
\hline 3. & $\mathrm{~T} 2$ & $\mathrm{~S}+40 \% \mathrm{vw}$ & 86.67 & 96.66 & 4.78 & 4.95 & 3.72 & 3.81 & 1.284 & 1.302 & 736.695 & 844.330 \\
\hline 4. & T3 & $\mathrm{S}+60 \% \mathrm{vw}$ & 76.67 & 80.00 & 7.31 & 7.44 & 3.69 & 3.8 & 1.994 & 1.967 & 1261.921 & 899.2 \\
\hline 5. & T4 & $\mathrm{S}+80 \% \mathrm{vw}$ & 100 & 100 & 7.85 & 7.98 & 4.24 & 4.29 & 2.043 & 2.053 & 1205.000 & 1227 \\
\hline 6. & T5 & $\mathrm{S}+100 \% \mathrm{vw}$ & 100 & 100 & 4.65 & 4.69 & 3.49 & 3.53 & 1.336 & 1.333 & 579.000 & 822 \\
\hline & & $\mathrm{CD}$ & $0.010256^{*}$ & $0.00001^{*}$ & $0.00001^{*}$ & $0.00001^{*}$ & $0.02802^{*}$ & $0.009926^{*}$ & $0.00001^{*}$ & $0.00001^{*}$ & $0.00001^{*}$ & $0.00001^{*}$ \\
\hline
\end{tabular}

$\mathrm{S}=$ soil, vw= vermiwash, R/S ratio $=$ Root/Shoot ratio, VI=Vigour Index, * $=$ Significant at $(\mathrm{P}<0.05)$ Level, ns $=$ non-significant

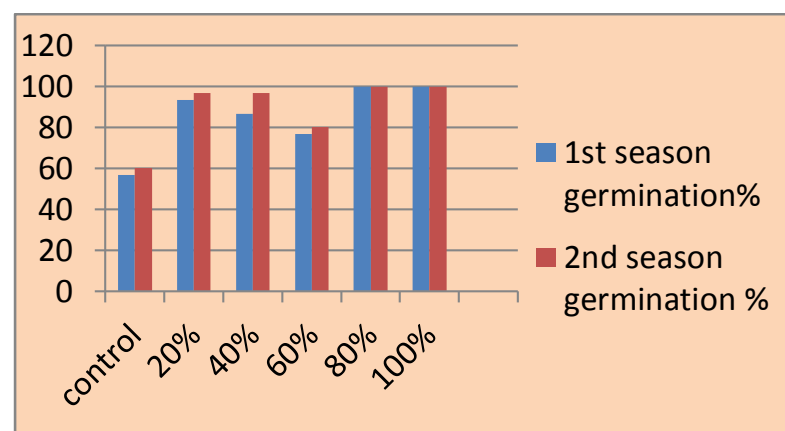

Vermiwash Concentration (\%)

Fig-5:Effect of vermiwash on seed germination

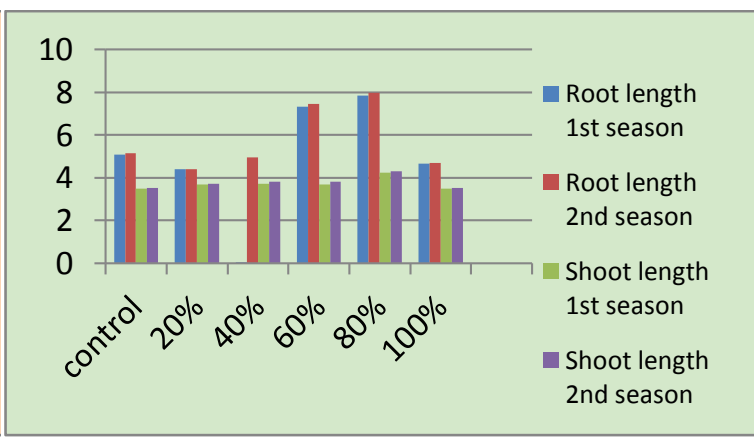

Vermiwash Concentration (\%)

Fig-6: Effect of vermiwash on root and shoot length

(cm) of C. roseus

Table 2. Physiochemical characteristics of vermiwash treated soil used in the study.

\begin{tabular}{|c|c|c|c|c|c|c|c|c|}
\hline $\begin{array}{c}\text { Sr. } \\
\text { No. }\end{array}$ & Treatments & Soil & PH & EC (dsm-1) & $\begin{array}{c}\text { Organic } \\
\text { carbon }\end{array}$ & Nitrogen & Phosphate & Potash \\
\hline 1 & T0 & Control & 6.3 & 0.25 & 0.87 & 304 & 75.96 & 274.4 \\
\hline 2 & T1 & S+20\%vw & 8.7 & 0.35 & 0.96 & 324 & 45.58 & 266.1 \\
\hline 3 & T2 & S+40\%vw & 6.6 & 0.53 & 0.80 & 290 & 78.65 & 271.6 \\
\hline 4 & T3 & S+60\%vw & 8.6 & 0.36 & 0.89 & 309 & 63.45 & 270.2 \\
\hline 5 & T4 & S+80\%vw & 8.5 & 0.42 & 1.50 & 438 & 89.37 & 274.4 \\
\hline 6 & T5 & S+100\%vw & 6.6 & 0.41 & 1.07 & 347 & 55.41 & 267.4 \\
\hline
\end{tabular}

$\mathrm{EC}=$ Electrical Conductivity, $\mathrm{S}=$ Soil Sample, $\mathrm{VW}=$ Vermiwash 